\title{
Polish Vasculitis Registry: POLVAS
}

To the Editor In 2014, we informed readers of this journal about the initiative to establish a Polish vasculitis registry. ${ }^{1}$ According to the recommendations of the European Union Committee of Experts on Rare Diseases (EUCERD), such registries should be created to help elucidate the numerous gaps in our knowledge about medical and social impact of these diseases on the health care system. ${ }^{2}$

It is now our pleasure to announce that the Scientific Consortium of the Polish Vasculitis Registry (Konsorcjum Naukowe Polskiego Rejestru Zapaleń Naczyń - POLVAS) has been created. The members of the Consortium include:

1 Jagiellonian University Medical College, Kraków (Leader) (Uniwersytet Jagielloński, Collegium Medicum): 2nd Department of Internal Medicine (II Katedra Chorób Wewnętrznych im. prof. Andrzeja Szczeklika)

2 Medical University of Gdańsk (Gdański Uniwersytet Medyczny): Department of Internal Medicine, Connective Tissue Diseases and Geriatrics (Katedra i Klinika Chorób Wewnętrznych, Chorób Tkanki Łącznej i Geriatrii); Department of Nephrology, Transplantology and Internal Diseases (Katedra i Klinika Nefrologii, Transplantologii i Chorób Wewnętrznych)

3 Wroclaw Medical University (Uniwersytet Medyczny im. Piastów Śląskich, Wrocław): Department of Rheumatology and Internal Medicine (Katedra i Klinika Reumatologii i Chorób Wewnętrznych) and Department of Nephrology and Transplantation Medicine (Katedra i Klinika Nefrologii i Medycyny Transplantacyjnej)

4 Medical University of Silesia (Śląski Uniwersytet Medyczny, Katowice): Department of Internal Medicine and Metabolic Diseases (Klinika Chorób Wewnętrznych i Metabolicznych); Department of Nephrology, Transplantation and Internal Medicine (Klinika Nefrologii, Transplantologii i Chorób Wewnętrznych); and Department of Internal Medicine and Rheumatology (Katedra i Klinika Chorób Wewnętrznych i Reumatologii) 5 Medical University of Lublin (Uniwersytet Medyczny, Lublin): Department of Rheumatology and Connective Tissue Diseases (Katedra i Klinika Reumatologii i Układowych Chorób Tkanki Łącznej)

6 Pomeranian Medical University in Szczecin (Pomorski Uniwersytet Medyczny, Szczecin): Department of Rheumatology, Internal Medicine and Geriatrics (Klinika Reumatologii, Chorób Wewnętrznych i Geriatrii)

7 National Institute of Geriatrics, Rheumatology and Rehabilitation, Warsaw (Narodowy Instytut Geriatrii Reumatologii i Rehabilitacji, Warszawa): Department of Rheumatology (Klinika i Poliklinika Reumatologii); Department of Early Arthritis (Klinika Wczesnego Zapalenia Stawów); and Department of Connective Tissue Diseases (Klinika Układowych Chorób Tkanki Łącznej) 8 Central Clinical Hospital of the Ministry of the Interior and Administration in Warsaw (Centralny Szpital Kliniczny MSWiA, Warszawa): Department of Internal Diseases and Rheumatology (Klinika Chorób Wewnętrznych i Reumatologii) 9 Military Institute of Medicine, Warsaw (Wojskowy Instytut Medyczny, Warszawa): Department of Internal Medicine and Rheumatology (Klinika Chorób Wewnętrznych i Reumatologii).

The POLVAS registry is designed for research purposes and includes retrospective and prospective databases. The retrospective part concentrates on epidemiology, clinical picture, as well as treatment safety and efficacy in the current routine care of vasculitis patients. The major aims of the prospective part include studies on pathogenesis, diagnostic and disease activity markers in serum, treatment efficacy and safety, long-term disease outcome including clinical and social consequences, and participation in clinical trials on novel therapeutic modalities in various vasculitis syndromes.

The members of the Consortium will also create vasculitis reference centers to offer the best possible diagnostic and therapeutic care for patients with vasculitis and to promote recent and future international vasculitis recommendations throughout the country. ${ }^{3,4}$

POLVAS will closely cooperate with other vasculitis registries created across Europe within the European Vasculitis Society (EUVAS) collaborative network. In association with the registry, a website for patients has also been created (www.zapalenianaczyn.pl) in order to provide a set of useful information about the various aspects of vasculitis syndromes.

Those who are interested in the cooperation with POLVAS are invited to visit the webpage at http://medicine.krakow.pl/POLVAS or contact the registry at POLVAS@cm-uj.krakow.pl. 
Acknowledgments This work was supported by the Leading National Research Centre (KNOW) 2012-2017; Faculty of Medicine, Jagiellonian University Medical College.

Author names and affiliations Jacek Musiał, Krzysztof Wójcik (2nd Department of Internal Medicine, Jagiellonian University Medical College, Kraków, Poland)

Corresponding author Prof. Jacek Musiał, MD, $\mathrm{PhD}$, II Katedra Chorób Wewnętrznych, Uniwersytet Jagielloński, Collegium Medicum, ul. Skawińska 8, 31-066 Kraków, Poland, phone: +4812 430 5314, e-mail: jacek.musial@uj.edu.pl

Conflict of interest The authors declare no conflict of interest.

How to cite Musiał J, Wójcik K, for POLVAS Consortium. Polish Vasculitis Registry: POLVAS. Pol Arch Intern Med. 2017; 127 (1): 71-72. doi:10.20452/pamw.3920.

\section{REFERENCES}

1 Padjas A, Sznaid J, Szczeklik W, et al. Rare disease registries: an initiative to establish vasculitis registry in Poland. Pol Arch Med Wewn. 2014; 124: $143-144$

2 Core Recommendations on Rare Disease Patient Registration and Data Collection. http://www.eucerd.eu/wp-content/uploads/2013/06/EUCERD Recommendations RDRegistryDataCollection adoped.pdf. Accessed September 2016.

3 Yates M, Watts RA, Bajema IM et al. EULAR/ERA-EDTA recommendations for the management of ANCA-associated vasculitis. Ann Rheum Dis 2016; 75: 1583-1594.

4 Sznajd J, Mukhtyar C. How to treat ANCA-associated vasculitis: practical messages from 2016 EULAR/ERA-EDTA recommendations. Pol Arch Med Wewn. 2016; 126: 781-788. 